\title{
Effect of Spray Volume on the Moisture of Stored Corn and Wheat Grains
}

\author{
Javier Alberto Vásquez-Castro ${ }^{1 *}$, Gilberto Casadei de Baptista ${ }^{2}$, Casimiro Dias Gadanha \\ Junior $^{3}$ and Luiz Roberto Pimentel Trevizan ${ }^{2}$ \\ ${ }^{1}$ Universidad Nacional Agraria La Molina; Depto. de Entomología; Av. La Universidad s/n; apartado 456, \\ Lima100; Peru; jaque@lamolina.edu.pe. ${ }^{2}$ USP/ESALQ; Departamento de Entomologia, Fitopatologia e Zoologia \\ Agrícola; ${ }^{3}$ Departamento de Engenharia Rural, C.P. 09; 13418-900; Piracicaba - SP - Brazil
}

\begin{abstract}
The goal of this work was to evaluate the effect of spray volume on the moisture of the stored grains of the corn and wheat. Two kg of each type of the grain were placed into the plastic bags and sprayed with the theoretical doses of $0,1,3,5,8$, and 10 liters of water / ton of the grain. The grain moisture content was evaluated 24 h after the spray operation by the oven method. The increase in the grain moisture was quadratic and showed the same trend in both the corn and wheat. The grain moisture after spraying 10 L.t $t^{-1}$ showed little increase (0.8\%) as compared to the initial moisture content. Thus, the application of any spray volume as used in this study made no difference for a possible better uniformity in the distribution of insecticide throughout the sprayed material.
\end{abstract}

Key words: Stored products, chemical control, application technology, desorption, hygroscopic equilibrium

\section{INTRODUCTION}

The moisture content is the most important factor for the grain preservation during the storage. The grain stored with high moisture contents is subject to high losses caused by the attack of the insects and fungi. Spraying the grain with the residual insecticides is the most important method of preventive pest control used in the storage facilities and in order to prevent the grain from regaining the moisture, the storage companies use

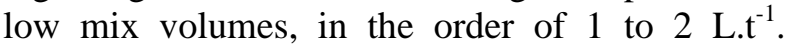
Studies have been conducted on the effectiveness and residues of the insecticides under the laboratory conditions, in which a variety of spray volumes were used, ranging from 0.7 L.t $\mathrm{t}^{-1}$ (Arthur et al., 1991) to 10 L.t $^{-1}$ (Daglish et al., 1996).

*Author for correspondence
Under the laboratory conditions, it is very difficult to treat the grain with low mix volumes, and disuniformity in the distribution of the insecticide may occur. On the other hand, high mix volumes favor the distribution of the insecticide, but can increase the grain moisture content up to the levels that may compromise its effectiveness. The maximum protection period provided by the insecticides depends mainly on the characteristics of the grain, and moisture content is one of the most important factors in the insecticide degradation (Fleurat-Lessard, 2002). The grain metabolic activity increases rapidly at the moisture contents higher than 14\% (Rowlands, 1967); Kretovich, cited by Rowlands (1967), observed that the enzymatic activity catalyzing the oxidation-reduction and hydrolysis reactions in the wheat grain increased markedly when the moisture content in the grain was higher than $15 \%$. Several authors have demonstrated a loss of the 
effectiveness in the organophosphorus insecticides in the corn and wheat grains at moisture contents higher than 14\% (Watters, 1959; Strong and Sbur, 1960, 1964; Rowlands, 1966; Samson et al., 1987). Samson et al. (1988) and Afridi et al. (2001) demonstrated that the organophosphorus insecticides were less stable than the pyrethroids in the corn and wheat grains with the moisture contents higher than $13 \%$. The objective of this work was to evaluate the effect of the spray volume on the moisture content of the corn and wheat grains under the laboratory conditions.

\section{MATERIAL AND METHODS}

A triple-stack yellow semiflint HT 98A corn hybrid and wheat cultivar BRS 208 were used, both developed by Empresa Brasileira de Pesquisa Agropecuária (EMBRAPA - Brazilian Company for Livestock and Farming Research). Spraying was achieved by placing $2 \mathrm{~kg}$ grain into the plastic bags; each bag received one of six water volume treatments: $0,1,3,5,8$, or $10 \mathrm{~mL} \cdot \mathrm{kg}^{-1}$, corresponding to the theoretical applications of 0 , 1, 3, 5, 8, and 10 L.t $^{-1}$. The applications were performed using a sprayer attached to an air compressor at a constant pressure of $150 \mathrm{KPa}$. During the spray, the plastic bags were agitated by hand, so as to allow the distribution of the liquid to be as homogeneous as possible. After spraying, the grains were kept inside the open plastic bags and stored in the laboratory under the uncontrolled conditions for a period of $24 \mathrm{~h}$, after which the water content in the grain was evaluated drying at
$105 \pm 3^{\circ} \mathrm{C}$ for $24 \mathrm{~h}$, according to Regras para Análise de Sementes - RAS (Seed Analysis Procedures) (Brazil, 1992). The temperature and relative humidity in the laboratory ranged from 20.3 to $27^{\circ} \mathrm{C}$ and from 36 to $55 \%$, respectively. Data analysis was performed by the analysis of variance, using a mathematical model for a completely randomized design in a factorial arrangement, and the $\mathrm{F}$ test was used to measure the significance of the factors (grain species, spray volume, and grain species $\times$ spray volume) in the model (Stell and Torrie, 1970; Pimentel-Gomes, 1987). The polynomial regression analysis was used to produce a detailed spray volume factor analysis.

\section{RESULTS AND DISCUSSION}

The analysis of variance for the corn and wheat grain moisture is presented in Table 1. There was a significant effect $(\mathrm{p}<0.0001)$ of the grain species and spray volume, but no effect of the species $\times$ volume interaction was observed. This indicated that the spray volume effect on the grain moisture was not species-dependent, i.e., the increase in the grain moisture owing to the sprayed water volume followed the same trend in both the corn and wheat. Significant effects were also observed in the linear $(\mathrm{p}<0.0001)$ and quadratic $(\mathrm{p}=0.0033)$ regressions. For this reason, the quadratic spray volume effect on grain moisture was used, since it was the effect with the highest significant regression degree (second-order polynomial).

Table 1 - Analysis of variance for corn and wheat grain moisture.

\begin{tabular}{lcccrc}
\hline \multicolumn{1}{c}{ Cause of Variation } & $\mathbf{D F}^{\mathbf{1}}$ & $\mathbf{S S}^{\mathbf{2}}$ & $\mathbf{M S}^{\mathbf{3}}$ & $\mathbf{F}$ & $\mathbf{P r}>\mathbf{F}$ \\
\hline Grain Species & 1 & 6.5878 & 6.5878 & 551.53 & $<0.0001$ \\
Spray Volume & 5 & 3.4722 & 0.6944 & 58.14 & $<0.0001$ \\
Linear Regression & 1 & 3.2208 & 3.2208 & 269.65 & $<0.0001$ \\
Quadratic Regression & 1 & 0.1271 & 0.1271 & 10.64 & 0.0033 \\
Regression Deviation & 3 & 0.1242 & 0.0414 & 3.47 & 0.0319 \\
Species $\times$ Volume & 5 & 0.0156 & 0.0031 & 0.26 & 0.9302 \\
Residue & 24 & 0.2867 & 0.0119 & & \\
Total & 35 & 10.3622 & & & \\
\hline
\end{tabular}

${ }^{1} \mathrm{DF}=$ Degrees of freedom; ${ }^{2} \mathrm{SS}=$ Sum of squares; ${ }^{3} \mathrm{QM}=$ Mean square.

Fig. 1 shows the curves fitted for the corn and wheat grain moisture. It can't be observed that both the curves were parallel and showed a quadratic increase $\left(0.0223 \mathrm{x}+0.0061 \mathrm{x}^{2}\right)$ as a function of the water volume applied. Therefore, the equivalent increases in the corn and wheat grain moisture contents were observed as sprayed water volume increased. Both the grain species were characterized by having high carbohydrate contents, which presented similar matrix potentials 
(Ngoddy and Bakker-Arkema, 1976); this characteristic explained the similar behavior of these grains.

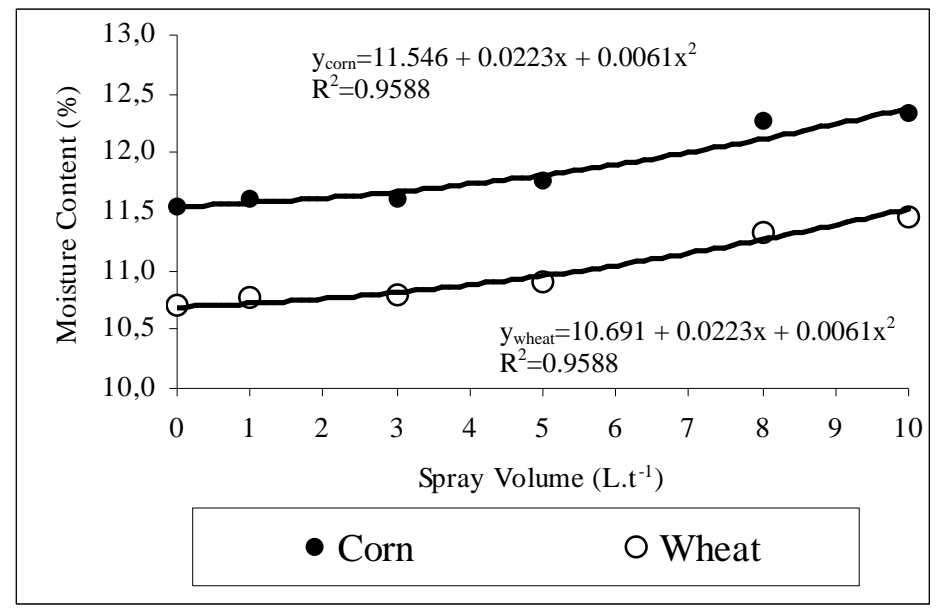

Figure 1 - Means and fitted curves for spray volume effect on corn and wheat grain moisture

The initial moisture contents of the corn and wheat grains were 11.5 and $10.7 \%$, respectively. This difference was due to the fact that each grain species came from a different storage facility, and during the storage the grains reached the equilibrium moisture contents corresponding to the particular temperature and relative humidity observed in each storage facility.

The grain moisture contents after spraying $10 \mathrm{L.t}^{-1}$ were, on average, 12.3 and $11.5 \%$ for the corn and wheat, respectively, thus demonstrating a $0.8 \%$ increase in relation to their initial values. It was likely that the grain moisture contents reached higher values right after the spraying. However, because of the characteristics of the laboratory environment in which the grains remained, such as the moderate temperature and, particularly, the low relative humidity, the moisture loss might have occurred, favored by the desorption process in the grain. According to Puzzi (2000), when exposed to the atmosphere, a small volume of the grain reached the hygroscopic equilibrium with the air relative humidity within a relatively short period.

Pixton and Warburton (1968) studied the time required for the wheat grain to reach the hygroscopic equilibrium when arranged in $1-\mathrm{cm}-$ thick layers, and observed that $90 \%$ of the total moisture reached the equilibrium after the second day in the desorption process, and after the fifth day in the adsorption process. The air humidity is of great importance for grain moisture content.
Thus, when the water vapor pressure in the air is lower than the water vapor pressure on the surface of the product, the grain will yield the water required to reach the equilibrium. In this respect, Bittencourt et al. (2000) observed a gradual moisture content decrease in the corn seeds after they were sprayed with the insecticides, and observed that the desorption process was influenced by the low relative humidity during the storage.

The results in the present study suggested that the water supplied by the insecticide sprays was adsorbed on the structure of the grain, making up part of the "free water", and was easily removed by the environmental factors. On the other hand, it was likely that the hygroscopic equilibrium in the sprayed grain had almost been reached, since, according to Macray, cited by Puzzi (2000), there were two grain moisture contents when it was in equilibrium at the same relative humidity. In the desorption process, the hygroscopic equilibrium was reached at higher moisture contents than in the adsorption process. In general terms, the sprayed grains showed relatively low moisture contents which, at first, did not compromise the insecticide effectiveness in controlling pests.

It was, therefore, concluded that the spray volumes studied here slightly increased the moisture contents of the corn and wheat grains under the laboratory conditions. Therefore, any of the spray volumes in this study can not be used, with the main objective of obtaining greater uniformity in 
the distribution of the mix throughout the mass of the grains.

\section{ACKNOWLEDGEMENTS}

The authors thank Carlos Eduardo Longatti for logistic support, Helena Pescarin Chamma, MSc., for the support with the grain moisture determinations, and Arlei Coldebella, Ph.D., for the statistical analysis.

\section{RESUMO}

A pulverização de inseticidas é o principal método de controle preventivo das pragas dos grãos armazenados. O objetivo deste trabalho foi avaliar o efeito do volume de pulverização na umidade de grãos de milho e trigo armazenados. Foram acondicionados $2 \mathrm{~kg}$ de grãos em sacos plásticos e pulverizados com doses teóricas de zero, 1, 3, 5, 8 e 10 litros de água / tonelada de grão. A avaliação do teor de umidade dos grãos foi feita 24 horas após a pulverização mediante o método da estufa. $\mathrm{O}$ acréscimo na umidade dos grãos em função do volume de água pulverizado, foi quadrático e teve a mesma tendência tanto para o milho como para o trigo. A umidade dos grãos após a pulverização de 10 L.t $^{-1}$ teve pequeno acréscimo $(0,8 \%)$ quando comparado com o teor inicial. Desse modo, é indiferente o uso de qualquer volume estudado, visando a maior uniformidade de distribuição do inseticida na massa de grãos.

\section{REFERENCES}

Afridi, I.A.K.; Parveen, Z. and Masud, S.Z. (2001), Stability of organophosphate and pyrethroid pesticides on wheat in storage. J. Stored Prod. Res., 37, 199-204.

Arthur, F.H.; Throne, J.E. and Simonaitis, R.A. (1991), Chlorpyrifos-methyl degradation and biological efficacy toward maize weevils (Coleoptera: Curculionidae) on corn stored at four temperatures and three moisture contents. J. Econ. Entomol.,84, 1926-1932.

Bittencourt, S.R.M.; Fernandes, M.A; Ribeiro, M.C. and Vieira, R.D. (2000), Desempenho de sementes de milho tratadas com inseticidas sistêmicos. Revista Brasileira de Sementes, 22, 86-93.

Brasil (1992), Ministério da Agricultura, do Abastecimento e da Reforma Agrária. Departamento
Nacional de Produção Vegetal. Divisão de Sementes e Mudas. Regras para análise de sementes. Brasília, $363 \mathrm{pp}$.

Daglish, G.J.; Eelkema, M. and Harrison, L.M. (1996), Control of Sitophilus oryzae (L.) (Coleoptera: Curculionidae) in paddy rice using chlorpyrifosmethyl or fenitrothion in combination with several other protectants. J. Stored Prod. Res., 32, 247-253.

Fleurat-Lessard, F. (2002), Qualitative reasoning and integrated management of the quality of stored grain: a promising new approach. J. Stored Prod. Res., 38, 191-218.

Ngoddy, P.O. and Bakker-Arkema, F.W. (1976), A generalized theory of sorption phenomena in biological materials (Part I. The isotherm equation). Transactions of the Asae, 13, 612-617.

Pimentel-Gomes, F. (1987), Curso de Estatística experimental. São Paulo: Livraria Nobel, 466 pp.

Pixton, S.W. and Warburton, S. (1968), The time required for conditioning to equilibrium with specific relative humidities. J. Stored Prod. Res., 4, 261-265.

Puzzi, D. (2000), Abastecimento e armazenagem de grãos. Campinas, Instituto Campineiro de Ensino Agrícola, $666 \mathrm{pp}$.

Rowlands, D.G. (1966), The activation and detoxification of three organic phosphorothionate insecticides applied to stored wheat grains. J. Stored Prod. Res., 2, 105.

Rowlands, D.G. (1967), The metabolism of contact insecticides in stored grains. Residue reviews, 17, 105-177.

Samson, P.R.; Bengston, M.; Parker, R.J. and Keating, J.A. (1987), The effect of grain moisture on the biological activity of fenitrothion residues on maize in storage. Pestic. Sci., 19, 135-144.

Samson, P.R.; Parker, J. and Jones, A.L. (1988), Comparative effect of grain moisture on the biological activity of protectants on stored corn. J. Econ. Entomol., 81, 949-954.

Stell, R.G.D. and Torrie, J.H. (1960), Principles and procedures of statistics - with special reference to the biological sciences. New York: McGraw-Hill, 481 pp.

Strong, R.G. and Sbur, D.E. (1960), Influence of grain moisture content and storage temperature on the effectiveness of malathion as a grain protectant. J. Econ. Entomol., 53, 341-349.

Strong, R.G. and Sbur, D.E. (1964), Influence of grain moisture and storage temperature on the effectiveness of five insecticides as grain protectants. J. Econ. Entomol., 57, 44-47.

Watters, F.L. (1959), Effects of grain moisture content on residual toxicity and repellency of malathion. J. Econ. Entomol., 52, 131-134.

Received: April 17, 2006; Revised: February 02, 2007; Accepted: January 04, 2008. 